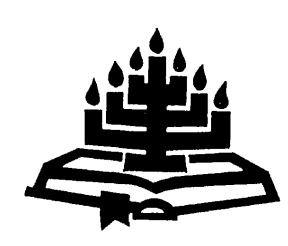

\title{
Bible reading in Africa: the shaping of a reformed perspective
}

\author{
B. Wielenga \\ Gereformeerde Sending \\ Richmond (KZN) \\ PIETERMARITZBURG \\ E-mail: wielenga@pmburg.co.za
}

\begin{abstract}
Bible reading in Africa: the shaping of a reformed perspective In this article I try to develop a reformed perspective on Bible reading in Africa by ordinary readers. I explore the concept of ordinary readers in the context of recent hermeneutical discussions, and of the differences between their mode of reading and that of biblical scholars against the background of the reality of the oral or semi-literate cultures of Africa. A reformed perspective, with its emphasis on the church as locus for Bible reading under the operation of the Holy Spirit, opens up a way forward out of the dilemma between ordinary and professional Bible reading. A reformed perspective can also clear the way for a gender-sensitive reading of the Bible in a continent where most Bible readers are women. This requires from those who read the Bible together an attitude of humility.
\end{abstract}

\section{Opsomming}

\section{Bybellees in Afrika: die vorming van 'n gereformeerde perspektief}

In hierdie artikel sal ek 'n gereformeerde perspektief probeer ontwikkel op Bybellees in Afrika deur gewone lesers. Ek bespreek die konsep van gewone lesers in die konteks van die jongste hermeneutiese diskussies, en van die verskille in die manier van Bybellees tussen gewone lesers en Bybelwetenskaplikes teen die agtergrond van die werklikheid van die mondelinge of halfgeletterde kulture van Afrika. 'n Gereformeerde perspektief, met sy nadruk op die kerk as die lokus van Bybellees, onder die werking van die Heilige Gees, maak die pad oop vorentoe weg van die dilemma tussen gewone en vakmatige lesers. 'n Gereformeerde perspektief kan ook die pad oopmaak vir 'n geslagsvriendelike lees van die Bybel op 'n kontinent waar 
die meeste Bybellesers vroue is. Dit vra van diegene wat die Bybel saam lees 'n houding van ootmoed.

\section{Introduction}

The greatest driving force behind the exponential growth of Christianity in sub-Saharan Africa in the twentieth century was the translation of the Bible in the vernacular (Sanneh, 1989; Bediako, 1995; Draper, 2006:181 ff.). The reception of the Bible in the vernacular strongly stimulated the cultural awareness of African peoples. That their own cultures were capable of receiving the written Word of God, revitalised their cultural self-esteem, and that in a time of western colonialism (Maluleke, 2000:102 ff.). ${ }^{1}$ One of the many consequences of Bible translation in the vernacular was that everyone who could read, was able to read the written Word of God. This led to what Sanneh has called the democratisation of Bible interpretation (Sanneh, 1989:174 ff.; Smit, 1998:309; Aichele, 2001:52). The protestant missionary movement in particular instigated school education with as goal to enable people to read the Bible for themselves. In this contribution I address the question of what happens to Bible reading when people are reading and interpreting the Bible for themselves. I discuss this question in the context of the present hermeneutical debate on Bible reading by ordinary people in nonwestern cultures (De Wit, 2004; 2007; Maluleke, 2000:90-95; West, 1991; 2000; De Wit \& West, 2008).

\section{Ordinary Bible readers}

The concept of "ordinary readers" has been developed within the tradition of Liberation hermeneutics (West, 2006). In this tradition the Bible is read as a book of society in the service of socio-political liberation from oppression (De Wit, 2004:8 ff.; 2007:71 ff.; Smit, 1998:305). In South-Africa Mosala (1989) has advocated this mode of reading in the context of the anti-apartheid struggle (West, 1991; Wielenga, 1992). West is quite clear that the ordinary readers, with whom socially engaged biblical scholars are involved, have developed a socio-political awareness and are influencing, in turn, their academically trained interlocutors (West, 2000:164 ff.; 2006:401; Anum, 2008:143 ff.). The Bible has been given to the "people". De Wit (2007:72) is aware that the conversation between the ordinary readers and the academic ones is not an easy one. Power and Testament translation on German culture. 
knowledge on the one side are often perceived as in opposition to expectation and hope on the other side.

Not everyone is at ease with this concept of ordinary readers. Maluleke (2000:93 ff.) offers a nuanced critique of West's usage of it. This concept presupposes oral, non-, or at best semi-literate Africans "reading" the Bible, whose "reading" is seen as just as valid and legitimate as the reading of academically trained, professional readers (De Wit, 2007:71 ff.). It requires a connectedness to grassroot Africans, which is really difficult to establish and sustain by academically trained professionals. However, the term itself is not helpful, in his opinion, because it does not give important information about these readers. Race, gender or class are not mentioned, while only these features influence Bible reading strongly according to the Liberation hermeneutics within which perimeters West wants to operate. Maluleke (2005) also points out some problems with the contrast between ordinary and trained Bible readers. Who designates these labels? Is the one designating not the one in power over and against the ordinary reader? One of the questions we have to address in this article is whether the academy can create the right locus for a conversation about the Bible and its meaning between professional and ordinary readers. The academic participants in the conversation are bound, as scholars within the western Enlightenment paradigm (Bosch, 1991:262-273; 1995:5-14) which is also the dominant paradigm in Africa, to the scientific regiment of their discipline (Van den Brink, 2004:30-88). ${ }^{2}$ We will argue, from a reformed perspective, that the church as the Spirit driven community of the saints is the intended place for such a conversation, where the problems, raised by Maluleke, can be overcome (Wielenga, 2009).

\section{Bible reading in Africa}

In this section I discuss the different problems faced by Bible reading in Africa.

2 See De Wit and West (2008) about the contentious relationship between western and African biblical scholarship. Nevertheless, modern African biblical scholarship starts from the in the West developed hermeneutical theories (cf. Anum, 2008:143 ff.). Theological concerns are rarely raised. 


\subsection{Professional Bible reading}

The great majority of Bible readers in Africa are people without special reading skills to enable them to correctly approach and understand the ancient texts. Their reading is not analytical and focused on understanding the original meaning of the texts. Professional readers, trained at western dominated academic institutions in the field of biblical sciences, focus on the reconstruction of the original meaning of the ancient texts in a complicated hermeneutical process (Smit, 1998). Even though West (2000:162) contends that the ordinary readers also influence the professional readers, the simple fact that the biblical scholars are in possession of all the knowledge needed to understand the ancient Bible texts in a responsible way, puts them in a position of power over their ordinary interlocutors. It is still clear that the majority of ordinary Bible readers in Africa are from an oral, non-, or at best semi-literate background. That gives the professional partners in reading-projects the upperhand. Interpretation and application of the Bible in the historical contexts of subSaharan Africa become so heavily dependent on academics, who, in spite of their best intentions, stand between the Bible and its readers. De Wit (2007:72 ff.; West, 2006:399 ff.), aware of this problem, argues that the naïve, spontaneous, precritical reading of these ordinary readers is absolutely legitimate and valid. The text requires this mode of reading, in which the concerns and interests of the reader and not those of the text per se, have to be taken care of. The ties between text and author have to be cut, with the consequence that the text becomes autonomous and can be understood in every new reading context. In this way the Bible grows in meaning in the ongoing process of reading and interpreting. 3 In the reactualisation process the original Bible text changes in meaning all the time. The academic sanction that this mode of reading receives, does not do away with the fact that trained professionals are the ones who authorise it and validate interpretations, which, sometimes, do not do justice at all to the Bible texts and sometimes even violate their interests. ${ }^{4}$ Once again, the academic reader comes between the ordinary reader and the One who is the principal Speaker behind the

3 See the title of Houtman's book (2006), De Schrift wordt geschreven, in which he addresses this very same problem.

$4 \quad$ It is in the text's interest to be understood and interpreted historically according to authorial intent so that the intended meaning can be found and applied in new contexts. See Fee and Stuart (1993). 
texts. He receives no room at all to make his voice heard through the medium of the Bible as historical document.

When these professionals are church leaders, or even, as in the past, western missionaries, their spiritual dominance in matters of Bible interpretation becomes a serious problem. Knowledge is power. Certainly in the past, missionaries could impose favoured Bible interpretations on their unskilled, sometimes even illiterate Bible believing flock. Of course, as Mbiti (2005:234-248) pointed out, much went wrong in the missionary dominated Bible instruction in subSaharan Africa. Western dominated readings of the Bible did not reach the hearts and minds of the African hearers. One of the problems, according to Molobi (Molobi \& Saayman, 2006:324-337), was that they tried to substitute the culture and religion of Africa with a belief system and a culture which did not touch the existential problems of the African people. Yes, a deep seated disdain for the primitive Africans made it impossible for them to take cognisance of their inherent norms and values, authority structures and belief systems. The missionary enterprise failed to reach the African public in spite of its great efforts to translate and interpret the Bible for an African audience. Molobi's analysis is common among the latest generation of African theologians (cf. Draper, 2006). Even the first Bible translations in the vernacular are said to betray the negative prejudices of their missionary translators, steeped in western style biblical scholarship, be it of a liberal or a conservative hue (Dube, 1999:33-59). The translated Bible itself posed a stumbling block, in her opinion, for African readers to really understand it.

\subsection{Ordinary Bible reading}

The ordinary readers approach the Bible contextually. They have no problem, as western readers have, with the strangeness of the cultures described in the Bible. They experience the Bible and especially the Old Testament as familiar (Draper, 2006:183-189). There are so many similarities between African cultures and the cultures in the Bible. The distance between the ancient text and the modern reader, created by history, is not perceived as a decisive hinderance in Bible application. Reading the Bible, one found so many answers to existential problems of everyday life that it became a much loved and revered Book. Without being aware of the original meaning of a text, not having the reading skills to discover the most plausible message of a passage, having no access to the peculiarities of the original languages of the Bible, in Africa the ordinary reader applies the Bible text directly, addressing the pressing problem of the mo- 
ment. Mbiti (2005:234 ff.) refers to so-called therapeutic readings of the Bible. One reads the Bible with a view of protection of life, threatened by illness or evil. Reading Psalm 1 and 2, or 20 and 40 against stomach ailments, in conjunction with the use of specially prepared holy water or herbal medicine, is an example of contextual, existential Bible reading (Mbiti, 2005:234 ff.; Adamo, 2000:337 ff.). It can even happen that the Bible in the oral cultures of Africa already functions as the authoritative Word of God without having been read at all (Ndung'u, 2000:243 ff.). Touching the holy Writ as an icon helps to make available the powers of life it contains. ${ }^{5}$

\subsection{Illiterate readers}

The majority of ordinary readers in Africa are illiterate, or at best semi-literate. This is true for many church leaders as well. Of course, school education, stimulated by mission in the past, has spread all over Africa. The many Bible translations in the vernacular have helped to increase reading and writing skills among ordinary people. In the wake of decolonisation education was a priority in many newly independent states. Nevertheless, most of the Bible readers are living in an oral, not in a literate culture. Not a culture of reading, but of hearing is paramount in many parts of sub-Saharan Africa. Also in a modern country as South Africa practical illiteracy is frightfully high, also among church leaders, who are called to instruct their flock in Scriptures. I want to address the question of how Bible reading takes place in such a culture. I make use of the research done in the relationship between auditivity and literacy by people like Walter Ong (1982; Loubser, 2004). ${ }^{6}$

In the context of this article, I want to highlight the following features of the impact of literacy on an oral culture, and vice versa.

\section{- $\quad$ Spoken language written down}

In an oral culture the language written down is strongly influenced by the spoken language. Oral traditions, transmitted throughout the ages with the aid of recognised mnemo-techniques, were written

5 See Sommer (2004:131 ff.) for the written torah as icon (an idea already present in the 7 th century $\mathrm{BC}$ ) in present rabbinic Judaism.

6 Also much research has been done in the relationship between orality and literacy in the Bible (Dundes, 1999; Niditch, 1996; Schniedewind, 2004; Draper, 2004; Van der Toorn, 2007). 
down just as one had heard them and remembered them. ${ }^{7}$ This resulted in spoken language written down. The features of the spoken language are still discernible in the recorded language. So, one did not experience the distance between the original speaker of the text and the text itself as important. The authority of the original speaker is decisive in receiving the recorded version of his speech. In an oral culture written texts were read out loud to an audience which could not read. The letters of Paul were read to the churches, and were experienced as addressed by him to them personally. In the oral cultures of Africa one experiences, behind the written Bible, the original Speaker, who gives authority to it as holy Writ.

\section{- Holy words}

In oral cultures, with a very low level of literacy, written texts are perceived as holy, filled with magic powers which exercise malicious or benevolent influence over their hearers (blessings or curses). In the ancient Near East reading and writing skills were found among temple personnel (Van der Toorn, 2007:27-108). This was also true in ancient Israel. The scribes were found especially among the Levites. They were commissioned to guard the holy texts of the covenant, which were kept in the sanctuary. Archives and libraries were found in temples in ancient times, underpinning the special status written texts had in oral cultures (Schniedewind, 2004:110; Van der Toorn, 2007:63). The Bible as a compilation of written texts also has in Africa a status of divine authority, even unread as we have seen.

\section{- $\quad$ Audio-community}

Listening together to spoken words binds the audience together in a community. Reading written words individually, isolates people from one another (Ong, 1982:72 ff.). Reading for oneself, individually, can have a destabilising effect on a community. Oral traditions, carried by the community throughout the ages, are replaced by written texts which everybody has, in principle, access to. In oral cultures, unsurprisingly, reading together or listening together to texts being read out, is more important than reading individually for oneself. This was clearly the case in postexilic Judah. Listening together to the reading of the book of the Law of Moses (Neh. 9) and its exposition tied the battered exiles together in a God-centered and temple-

7 In the transmission of oral traditions variations occur between different tradition streams, which are found in the written versions (Niditch, 1996:27 ff.; Dundes, 1999:21 ff.). The modern concern for historical exactness was absent. 
based community. Bible reading in Africa is more a communal than an individual event.

\section{- $\quad$ Reading specialists}

As soon as oral traditions are written down, the connection between the speaker(s) and the written versions becomes loose. A written text in an oral culture requires explanation and application by people who are able to read, namely the scribal class. The hermeneutical problem is born (Aichele, 2001:40-45). The scribal class is also responsible for hermeneutics and exegesis. The audience becomes dependent on them for the correct interpretation of the words read. This opens room for a different approach to written texts, as occurred in the West. The texts as they are written down becomes the final authority, and not the original authors who gave them a status of authority in the first place. In Africa, semi-literate, ordinary people are never at an equal footing with professionally trained academic Bible readers.

\section{- $\quad$ Preservation of the holy Writ}

Traditions were written down to prevent them from getting lost in times of social crisis and political upheaval as was the case after the exile in ancient Israel (Watts, 2001). 8 The written form of the Law of Moses as a book preserved its content and stimulated the community's obedience to it. After the exile, the canonisation process started in earnest (Schniedewind, 2004:64-138; Van der Toorn, 2007:233-264). In oral or semi-literate cultures, the authority of the written Bible is undisputed; in the sophisticated reader-centered cultures of the West, scriptural authority is under siege.

We contend that the impact orality has on the approach to written texts and its reading in general, as outlined above, influences Bible reading by ordinary readers in Africa.

\subsection{Female readers}

In Africa, the majority of ordinary readers are women (and children). As a male, one does not need to be a feminist or womanist theologian (Keane, 1998:121-136; Ackermann, 1998:349-358; Oduyoye, 1998:359-372) in order to discern a real problem here. The majority

8 Horsley's (2004:107-134) opinion that written texts were used in the colonisation of subjugated people is not very helpful with regard to the making of the recorded Bible. 
of Bible readers are female, while the Bible preachers and teachers are mainly male. Even if one rejects the Bible's critical approaches of liberation hermeneutics, one is still capable to recognise that approaches to women found in the Bible, are different from some practises in many churches. ${ }^{9}$ Africa is patriarchal and women oppression is the rule rather than the exception.10 That is also true for South-Africa, where gender rights are protected by the Constitution and its Bill of Rights. The Bible seems to affirm this patriarchal tendency at face value in most of its parts. The message of the Bible has to be reclaimed as a life giving force also for women, and to be shown not to be life threatening to them.

\subsection{Is everyone teachers of the Bible?}

Considering the situation in which the Bible is read in Africa, the question which arises is whether every potential reader is really competent, capable of understanding and interpreting the Bible. Who determines which interpretation of the Bible is valid and legitimate? Especially in churches with a protestant-evangelical background this is a pertinent question. In church history it has received different answers. In some churches the academically trained clergy decides in one way or another how the Bible has to be read and understood. Other churches decide about this crucial question at their ecclesiastical meetings in line with ancient creeds which publicly function as norma normata in matters of Bible interpretation, containing the officially accepted results of Bible reading of the past generations (Kamphuis, 2000:135 ff.). Since the Reformation the freedom of exegesis (libertas prophetandi) has been strongly defended in reformed churches (Van der Dussen, 2007:22 ff.; Matheson, 2006:75), but most of them have outlined specific ecclesiastical procedures through which this freedom has to be exercised, especially when this freedom conflicts with the accepted readings of the Bible, as laid down in the creeds. 11 In the reformed tradition, the

$9 \quad$ See the volume edited by De Wit (2004), which focuses on reading John 4 (the Samaritan woman) with ordinary participants from all over the world.

10 Newspapers reported in 2009 that allmost $25 \%$ of South African men have raped a woman once or more in their lives.

11 For the different ecclesiastical systems, see GKSA (1980:7-13). For the subscription to the creeds, see GKSA (1980:25, 82 ff.; DKO art. 53). For a recent evaluation of the discussion about Bible reading within the GKSA, see B.J. van der Walt (2008). See De Gruchy (2009:147 ff.) on confessions and interpretations in the reformed traditions since Calvin. 
so-called democratisation of Bible interpretation has never really taken off. Church history teaches us that not every reader is a competent reader. This general rule is even more true when it comes to reading the Bible, which is an ancient, literary and historically difficult text (Houtman, 2006). One has to face squarely the many conflicts around the Bible and its reading (Smit, 1998:297-318; 2006), not only in illiterate African cultures, but also in literate ones worldwide. In Africa much Bible interpretation is fruit of superficial, fanciful and erratic reading, too often a consequence of a lack of competent reading skills, even among church leaders. Overcontextualisation, as shown by the examples given by Mbiti and Adamo (see above), is a constant problem. A strong moralistic and associative reading is common among many African instituted churches, as well as in mission instituted churches, where the Bible is in high esteem (Ndung'u, 2000:243). What can be expected of a conversation between professional and ordinary readers in this semi-literate reading climate? Of course, in some postmodern circles, as we have already seen, reading is perceived as producing meaning, giving meaning to the text (Smit, 1998:309; Tate, 2006:523 ff.; De Wit, 2007:71 ff.). The focus then, is not on the authorial intent behind the text, but on the readers in front of the text (West, 1991:124 ff.). How they respond to what they read in their existential situation constitutes as legitimate a meaning as the one found by the professional reader in his academic context. However, Smit (1998:309) asks if all readings are equally valid and worth taking note of, when they are all productions of meaning. Is no one controling, in one way or another, the reading process, and so the production of meaning? Does everything go in a sort of do-it-yourself exegesis?12 These questions undermine the academic justification of meaningful Bible reading by African ordinary readers. We agree with Smit (1998:310) that we have to go for a responsible reading of the Bible, taking into account the constraints of the texts with their language indicators to which reading is textually possible or plausible. We are in need of a different model of Bible reading in Africa, which promotes the conversation between professional and ordinary readers in a different context, namely the church where the indwelling Holy Spirit distributes his gifts souvereignly. Not all are Bible teachers (cf. 1 Cor. 12:28-29). In other words, not everybody's reading is valid, legitimate and acceptable. Not everything goes.

12 See the recent study by Van Rensburg and Kruger (2008), aiming to help ordinary readers within an Afrikaner context with reading the Bible. 


\section{A reformed model}

In the following section some principles for responsible Bible reading in Africa will be formulated. I zoom in on the community of faith as hermeneutical principle and the work of the Holy Spirit will be discussed as non-negotiable for Bible reading, (redemptive-) historical Bible reading will receive attention, and finally, gender sensitive reading must be explored. These principles will, however, not be discussed in full - their significance and relevance for ordinary Bible readers in Africa will only be highlighted. I conclude the deliberations by stressing the importance of a spiritual approach towards the conversation between professional and ordinary readers of the Bible.

\subsection{The church as Bible reading community}

In the reformed tradition the Bible is seen as the book of the church as the people of God, and not of the "people" as such.13 Matheson (2006:71) notes that in the time of the Reformation it were just ordinary people who were empowered by being able to read the Bible in the vernacular. They were provided with "an unchallengeable authority to back their awkward and probing questions". Reformed creeds as the Belgic Confession (1561) or the Westminster Confession (1647) pay quite some attention to the Bible as a religious document, containing the Word of God. Instigated by the Holy Spirit, the revealed Word of God was committed to writing. Within the reformed tradition the Bible plays a central and crucial role in church and theology. 14 The practicing of the pure preaching of God's Word is confessed to be the main mark of a true church (Belgic Confession, Art. 29). And this Word alone (sola Scriptura, cf. De Gruchy, 2009:144 ff.), as it is found in the Bible, may be preached, because it is seen as medium gratiae (Trimp, 1985:7).15 The preaching of the gospel, as found in the canonical Scriptures, is the main key with which God opens or closes his kingdom (Heidelberg Catechism, Lord's Day 31/83, 84). Assumed in this vision of

13 We do not deny that the Bible can also be read outside the church under the operation of the Holy Spirit.

14 For the GKSA, see the recent discussion between Van Wyk and G. Snyman (Van Wyk, 2008).

15 Trimp (1985) refers to Heidelberg Catechism, Lord's Day 35/98: the living preaching of God's Word is the medium used by God for instruction of his people. 
the Bible as living Word of God is the belief in God as the One who speaks to his people, who are called to hear. The church is a faith community of people who are hearing the Word of God preached and taught to them, (Acts 2:42; Rom. 10:14-17; Hoek, 1996:420 ff.). This approach is based upon the covenantal structure of biblical religion (Trimp, 1985:16 ff.). The teaching of Calvin (1949 [1559] Institutio IV.1.5; De Gruchy, 2009:140) forms the theological background of this Bible-centered approach to preaching. The Bible is given to the church to be preached in Sunday worship (Smit, 2006: 19 ), but also in pastoral work at the homes of its members (Trimp, 1985:17). In small growth and care groups the Bible is read and applied in the personal situations of its participants, the ordinary members of the church. In the Bible-centered family worship, the spiritual formation of the family members is taken care of. In their quiet times, individual Bible readers are spiritually formed as well (Peterson, 2005:13). In the Bible ministries of the church, the academically trained and publicly ordained minister of the Word (Verbi Divini Minister) plays a crucial role. Therefore, in the reformed tradition the locus for the conversation between professional and ordinary readers has always been the church in its different formations and ministries. It goes without saying that reformed churches never limited themselves in their ministries to their own membership. Their missionary dimension has, at least in theory, always been recognised. In reformed missions a foundational role has always been given to the preaching and teaching of the Bible (Matt. 28:19; Haak, 2005:15; Wielenga, 1998:277).

In conclusion, in the church the professional and ordinary readers come together before the Lord, who speaks to them through the Bible (per verbum and cum verbo; cf. Veenhof, 2008:258), as preached and taught by the ordained ministers. Everybody ought to have access to the Bible in the vernacular, but not everybody is called to teach and preach the Bible. 16 Not everybody has received the gifts needed for understanding and interpreting the Bible. This is not in conflict with the doctrine of the claritas scripturae (Berkouwer, 1966-1967:247-330). This doctrine does not deny that the Bible as ancient text is difficult to read and needs quite some prior knowledge in order to make understanding and interpreting possible. The claritas refers to the Bible as medium gratiae, the recognition in faith

16 On the relationship between academic theology and the (Bible) ministries of the church, see De Bruijne (2004:11-30). On theology as academic discipline, see Van den Brink (2004). 
of the One who speaks through it to the community of the hearers of the Word. In Africa, ordinary and professional readers have been given to one another by the Spirit, everybody with his/her own gifts, to build up the church as the body of Christ. It is the calling of (trained) pastors and teachers in the church of Africa to serve God's people to bring them to maturity in Christ (Eph. 4:11-16). Biblical scholarship is called to facilitate the encounter between the ordinary Bible readers and the One who speaks to them through its words. ${ }^{17}$

\subsection{The work of the Holy Spirit}

Two issues have to be addressed in this paragraph. The question can be raised if ordinary readers do not become overdependent on church leaders as professional Bible readers for their understanding of God's Word. Especially in Africa, where (charismatic) church leaders play a central role in their communities, it could be spiritually unhealthy to emphasise their importance as Bible interpreters. So they could become the chief intermediaries between their flock and God with as consequence the dependence of ordinary readers on their spiritual leadership. This could be offset by a church membership which becomes more and more trained in the skills of Bible reading and understanding. Another question is how the chaos of a democratised Bible interpretation can be overcome. Too often the so-called ordinary understanding of the Bible leads to spiritual turmoil and the undermining of the authority of the Bible, which is unassailably high in Africa. The practice in African instituted churches is a case in point. At the end, everybody is left with their own Bible (Wielenga, 1992:30).18 An endless fragmentation of the church follows. The price to be paid for a democratisation of Bible interpretation is too high indeed. In the reformed tradition the testimony of the Holy Spirit has always been raised to address both these questions (Berkouwer, 1966:41-82; Van Keulen, 2003:479 ff.). ${ }^{19}$ । highlight the following aspects, relevant for this discussion.

17 I leave out a discussion on the relationship between the catholicity of the church and Bible interpretation (cf. Smit, 2006:88-110).

18 See Matheson (2006:72) for the chaotic results of Bible reading by ordinary people in the time of the Reformation in Europe (cf. also Balke, 1973).

19 See Van den Belt (2007:346-360) and also Smit (2006:192 ff.). Also here the teaching of Calvin forms the background of reformed theology (Balke, 1973:338344; Van der Kooi, 2002:90, 97; De Gruchy, 2009:141 ff.). 
It is through the work of the Holy Spirit that we have received the canonical Scriptures (Berkouwer, 1966:83-138; Van Keulen, 2003: $486 \mathrm{ff}$.). ${ }^{20}$ Through his work with and through the Bible He convinces us, as its readers, that it contains the living Word of God. Therefore, it is the Bible itself which convinces us of which interpretation is meant and intended by the Spirit and which one not. The Bible has authority in itself (autopistos), and effectuates it under the operation of the Holy Spirit. Of course, this work of the Holy Spirit does not make the hermeneutical and exegetical efforts and skills of the biblical scholar superfluous. These are necessarily included.21 Bible reading skills are gifts, bestowed upon him/her by the Spirit in order to serve the faith community. 22 In the oral or semi-literate cultures of Africa, faithful biblical scholarship is an instrument in the hands of the Spirit to convince people of what God wants to say to them in the Bible. Within the church as the community of the saints both professional and ordinary readers are dependent on the work of the Spirit in and among them. So they become mutually interdependent on one another within the Spirit driven church. For the correct exercise of their Bible reading skills and gifts, professional readers need the ordinary readers as interlocutors to create the right, spiritual reading climate within the Bible reading community so that the Spirit finds room to effectuate his illuminating powers among them.

Against the danger of spiritual autocracy of church leadership in Africa, the Spirit uses biblical scholarship to develop the reading skills of ordinary readers in order to let them grow in maturity of faith and to make them more assured in their Bible knowledge when dealing with autocratic church leadership. The chaos of a democratised Bible interpretation is silenced by the Spirit. With and through the Bible the Spirit convinces the hearts of the hearers of what it is that God wants to say to them.

20 For a thorough, scholarly discussion of the biblical canon, see McDonald and Sanders (2002).

21 See Van Wyk (2008:695 ff.) about the importance of pneumatology for Bible reading. This is not meant as a goedkoop ontsnappingsmeganisme for serious scholarship. Postmodern biblical hermeneutics is pneumatologically flawed.

22 For the relationship between the gifts of the Spirit and creational skills, see Smouther (2006:108-124). 


\section{3 (Redemptive-) historical reading23}

Many ordinary readers in Africa experience much in the Bible as familiar. They may apply, prescriptively, moral rules or cultural customs, found there, on an one-to-one basis into their own situation. In Leviticus 11-15, the laws with regard to ritual purity, they may discover rules and regulations which compare favourably with what is entrenched in their own cultures and religions. Many feel at home especially in the Old Testament. The difference between what is prescriptive in the Old Testament laws and what is culturally descriptive, may not be noticed. The concept of progressive revelation is mostly unknown to them. The development of salvation history which can be discerned in the Old Testament itself, and canonically, from the Old Testament into the New Testament, does not play an important role (Helberg, 1983; De Jong, 2002; Wright, 2006). They may be not aware of the historical character of the Bible with its culturally shaped features (Houtman, 2006). They often miss the reading skills and knowledge to detect it. In the oral or semi-literate cultures of Africa, what is written in the Bible is often seen as being indisputably true and authoritative, holy as the text is perceived to be, spoken by the holy One. Not only ordinary readers make easy comparisons between African cultures and religions and what they read in the Bible, but also professional biblical scholars have tried to point out these comparisons (Anum, 2000:458 ff.). Some have been motivated by the desire to sanction the traditional African cultures and religions as praeparatio evangelica in the face of colonial disdain of African culture. This comparative research model is, however, scientifically not uncontested (Anum, 2000; West, 2008:41 ff.). The familiarity of especially the Old Testament in Africa is actually an ideological delusion, if one takes into account the canonical form of the Bible with its kerugmatic scope (Wielenga, 1992; 1994; cf. also Peels, 2009), which opens the eye for the progressive revelation which characterises canonical Scripture. This implies that one reads the Bible with a view on Christ, the kerugmatic centre of Scriptures. 24 It is impossible to read the canonical Scriptures against this christological grain, applying all sorts of Old Testament pas-

23 A still valuable introduction to redemptive-historical Bible reading is Greidanus (1988; compare also his earlier study, 1970). See also Helberg (1983:59-70) and König (2002:188 ff., 214 ff.).

24 See Van Keulen (2003:526 ff.) on Berkouwer's concept of the scope of the Bible. See Wolterstorff (2004:217-232) for a philosophical underpinning of this concept. 
sages to concrete, historical contexts without even mentioning the name of Jesus Christ and what He stands for. De Jong (1984) calls this an "earthly-minded" (aardsgezind) reading of the Bible, which despiritualises its message. The Bible does not teach us to look at this world and this worldly affairs without our eyes firmly fixed upon Jesus Christ and Him crucified.25 In Africa, Bible reading occurs even without faith in Jesus Christ, who may have been replaced, for instance, by someone like Isaiah Shembe, the founding father of the iBandla lamaNasaretha in KwaZulu-Natal.

\subsection{Gender sensitive reading}

As pointed out, most of the ordinary Bible readers in Africa are women, forming the vast majority of the church's membership. Even though reformed theology in general does not have much sympathy for feminist theology, it is hermeneutically regarded to be part and parcel of Liberation theology (Sawyer, 2006:464-479).26 This does not mean that this theology has not raised some very real issues which need to be addressed (Van de Beek, 2006:235-241; Verkerk, 1997; Verkerk \& Verkerk-Vegter, 2005), especially in the context of African Christianity (Van Wyk, 1993:73 ff.). It is possible to approach the male-female relationship from the perspective that both have been created in God's image (Van Wyk, 1993:16). The differences and similarities between the sexes do not have to receive all the attention. Male and female together find their unity in their unique creation in God's image. In each person, male or female, God is intimately present (Verkerk \& Verkerk-Vegter, 2005:164), and gives each one his directives, to which they have to respond in concrete, daily obedience. Being human means living in a word-response relationship with God the Creator (Geertsema, 1992), which has to be renewed on a daily basis by the Holy Spirit. Male and female participate in that relationship, each in his/her own uniqueness as created by God. This approach presumes a basically equal position between male and female in spite of the gender differentiation.27 This should encourage gender sensitive Bible reading, which discourages women oppressive Bible teaching in churches.

25 For a systematic approach to this christological Bible reading, see Van de Beek (2001).

See De Gruchy (1991) for incorporating Liberation hermeneutics in reformed theology.

27 For a biblical theological perspective, see De Jong (1994:64-83). 


\section{Bold humility 28}

The encounter between highly trained, academic and semi-literate ordinary Bible readers in Africa requires a truly spiritual attitude of both participants in the conversation for it not to become a failure, as it too often has been in African church history. As argued above, the most appropriate locus for such a conversation should be the church as the Bible believing community of the saints, the Spirit driven body of Christ. The best place to look for a description of such an attitude is the Bible itself. Bosch (1979) draws an outline of the spiritual attitude a missionary needs in order to fulfil faithfully his calling, based on Paul's second letter to the Corinthian church. He ends his portrait with a chapter on the courage to be weak (Bosch, 1979:75 ff.), referring to 2 Corinthians $12: 10$. We contend that it is this weakness which is asked for from the professional Bible readers in their encounter with the ordinary ones within the community of faith. They have been given their gifts, and could develop their skills, under the operation of the Holy Spirit with a view to serve their fellow believers. This implies, at least, the following characteristics.

- The professional readers should be listeners before they speak. Before they go and impart their knowledge, they should understand where their interlocutors are.29 A relationship of trust has to exist. They do not place themselves arrogantly above the ordinary readers, but next to them as fellow cross-bearers following the crucified Christ. Their participation in Bible reading ministries is not about academic point scoring. They must be seen as loyal and trustworthy partners in Bible reading together.

- In the case of western professionals among African ordinary readers, paternalism which wants to control the process through intimidating knowledge disclosure has to be avoided at all costs. ${ }^{30}$ As fellow disciples of Christ we are together dependent on the one and same Spirit. They have to cross a cultural frontier in order to become as much one with their fellow readers as is humanly possible. This requires cultural adaptability and the willingness to be taught and learn from their fellow Bible readers. Apart from the distorting influence of academic knowledge, the 
danger of financial aid to poor church communities also has to be taken into account by western professionals. Bible ministries in Africa have been controlled from overseas by selective funding (Breman, 1996).

- According to John 15, biblical scholars can only be fruitful in their chosen field in service of the church and its ordinary readers when they as branches are connected with the vine, the risen Christ (Burger, 2009:363-366). In sum, they need true humility, which is bold in facing the problems and pitfalls which bedevil reading the Bible together or listening together to what the Spirit wants to say to the readers.

The ordinary readers should display a willingness to be taught, showing respect because of what they receive, even following the example of faith set by their teachers (Heb. 13:7). In a situation of doctrinal confusion the first readers of the letter to the Hebrews were called upon even to submit to their leaders, who spoke the Word of God to them (Heb. 13:17) in order to stay on course to the future promised to them. That reading the Bible together goes with praying together has been correctly pointed out by T. van der Walt (2008: 756).

\section{List of references}

ACKERMANN, D. 1998. Feminist and womanist hermeneutics. (In Maimela, S. \& König, A., eds. Initiation into theology: the rich variety of theology and hermeneutics. Pretoria: Van Schaik. p. 349-358.)

ADAMO, D.T. 2000. The use of Psalms in African indigenous churches in Nigeria. (In Dube, M.W. \& West, G.O., eds. The Bible in Africa: transactions, trajectories and trends. Leiden: Brill. p. 336-349.)

AICHELE, G. 2001. The control of biblical meaning: canon as semiotic mechanism. Harriburg: Trinity.

ANUM, E. 2000. Comparative readings of the Bible in Africa: some concerns. (In Dube, M.W. \& West, G.O., eds. The Bible in Africa: transactions, trajectories and trends. Leiden: Brill. p. 457-473.)

ANUM, E. 2008. Collaborative and interactive hermeneutics in Africa: giving dialogical privilege in biblical interpretation. (In De Wit, J.H. \& West, G.O., eds. African and European readers of the Bible in dialogue: in quest of a shared meaning. Leiden: Brill. p. 143-165.)

BALKE, W. 1973. Calvijn en de doperse radikalen. Amsterdam: Bolland.

BEDIAKO, K. 1995. Christianity in Africa: the renewal of a non-western religion. Edinburg: Edinburg University Press.

BERKOUWER, G.C. 1966. De heilige Schrift. Vol. 1. Kampen: Kok. (Dogmatische Studiën.)

BERKOUWER, G.C. 1967. De heilige Schrift. Vol. 2. Kampen: Kok. (Dogmatische Studiën.)

BOSCH, D.J. 1979. Spirituality of the road. Scottsdale: Herald. 
BOSCH, D.J. 1991. Transforming mission: paradigm shifts in theology of mission. Maryknoll: Orbis Books.

$\mathrm{BOSCH}$, D.J. 1995. Believing in the future: toward a missiology of western culture. Harrisburg: Trinity Press International.

BREMAN, C.M. 1996. The Association of Evangelicals in Africa: its history, organization, members, projects, external relations and message. Zoetermeer: Boekencentrum. (Mission 13.)

BURGER, H. 2009. Being in Christ: a biblical and systematic investigation in a reformed perspective. Eugene: Wipf \& Stock. (D.Th. thesis; ThUK 2.)

CALVIN, J. 1949 [1559]. Institutio Christianae religionis. Trans. by A. Sizoo as Institutie of onderwijzing in de Christelijke godsdienst. 2nd. ed. Delft: Meinema.

DE BRUIJNE, A.L. Th. 2004. Gereformeerde theologie vandaag. (In De Bruijne, A.L. Th., red. Gereformeerde theologie vandaag: oriëntatie en verantwoording. Barneveld: De Vuurbaak. p. 11-30.)

DE GRUCHY, J.W. 1991. Liberating reformed theology: a South African contribution to an ecumenical debate. Grand Rapids: Eerdmans.

DE GRUCHY, J.W. 2009. John Calvin: christian humanist and evangelical reformer. Wellington: Lux Verbi.BM.

DE JONG, H. 1984. Zij zijn "aardsgezind", 1-4. Opbouw, 28:18-21.

DE JONG, H. 1994. Paulus' gebruik van Genesis 1-3 inzake de man-vrouwverhouding. (In Bouma, J., Dekker, J., Van Leeuwen, A.M. \& Muller, K., reds. Begeleidend schrijven: 25 jaar theologische studie begeleiding. Amsterdam: Buijten \& Schipperheijn. p. 64-83.)

DE JONG, H. 2002. Van oud naar nieuw: de ontwikkelingsgang van het Oude naar het Nieuwe Testament. Kampen: Kok.

DE WIT, J.H. 2004. Through the eyes of another: objectives and background. (In De Wit, J.H., Jonker, L., Kool, M. \& Schipani, D., eds. Through the eyes of another: intercultural reading of the Bible. Elkhart: Institute of Mennonite Studies. p. 3-53.)

DE WIT, J.H. 2007. Wereldwijd Bijbellezen: dogmatiek, exegese en gewone gelovigen. (In Den Hertog, G.C. \& Van der Kooi, C., reds. Tussen leer en lezen: de spanning tussen Bijbelwetenschap en Geloofsleer. Kampen: Kok. p. 69-86.)

DE WIT, J.H. \& WEST, G.O., eds. 2008. African and European readers of the Bible in dialogue: in quest of a shared meaning. Leiden: Brill.

DRAPER, J.A. 2004. Orality, literacy and colonialism in antiquity. (In Draper, J.A., ed. Orality, literacy, and colonialism in antiquity. Leiden: Brill. p. 110.)

DRAPER, J.A. 2006. Africa. (In Sawyer, J.F.A., ed. The Blackwell companion to the Bible and culture. Oxford: Blackwell. p. 176-197.)

DUBE, M.W. 1999. Consuming a cultural, colonial bomb: translating Badimo into Demons in the Setshwana Bible. Journal for the study of the New Testament, 73:33-59.

DUNDES, A. 1999. Holy writ as oral lit: the Bible as folklore. Lanham: Rowman \& Littlefield.

FEE, D.G. \& STUART, D. 1993. How to read the Bible for all its worth: a guide to understand the Bible. 2nd ed. Grand Rapids: Zondervan.

GEERTSEMA, H.G. 1992. Het menselijk karakter van ons kennen. Amsterdam: Buijten \& Schipperheijn. 
GEREFORMEERDE KERKE IN SUID-AFRIKA. 1980. Kerkorde van die Gereformeerde Kerke in Suid-Afrika (soos gewysig deur verskillende sinodes). Potchefstroom: Calvyn Jubileum Boekefonds.

\section{GKSA}

\section{kyk GEREFORMEERDE KERKE IN SUID-AFRIKA}

GREIDANUS, S. 1970. Sola Scriptura: problems and principles in preaching historical texts. Kampen: Kok. (D.Th. thesis; ThUK 1.)

GREIDANUS, S. 1988. The modern preacher and the ancient text: interpreting and preaching biblical literature. Grand Rapids: Eerdmans.

HAAK, C.J. 2005. Gereformeerde missiologie en oecumenica: beknopt overzicht aan het begin van de 21e eeuw AD. Zwolle: De Verre Naasten.

HELBERG, J.L. 1983. Verklaring en prediking van die Ou Testament. Potchefstroom: Potchefstroomse Teologiese Publikasies.

HOEK, J. 1996. Geheim en gestalte van de gemeente: over de kerk. (In Van den Brink, G., Van Campen, M. \& Van der Graaf, J., reds. Gegrond geloof: kernpunten uit de geloofsleer - in Bijbels, historisch en belijdend perspectief. Zoetermeer: Boekencentrum. p. 401-434.)

HORSLEY, R.A. 2004. The origins of the Hebrew Scriptures in imperial relations. (In Draper, J.A., ed. Orality, literacy and colonialism in antiquity. Leiden: Brill. p. 107-134.)

HOUTMAN, C. 2006. De Schrift wordt geschreven: op zoek naar een christelijke hermeneutiek van het Oude Testament. Zoetermeer: Meinema.

KAMPHUIS, B. 2000. Geloofszekerheid en de binding aan de belijdenis. (In Van Bekkum, K. \& Rouw, R., eds. Geloven in zekerheid? Gereformeerd geloven in een postmoderne tijd. Barneveld: De Vuurbaak. p. 135-150.)

KEANE, M-H. 1998. Feminist and womanist theology. (In Maimela, S. \& König, A., eds. Initiation into theology: the rich variety of theology and hermeneutics. Pretoria: Van Schaik. p. 121-136.)

KÖNIG, A. 2002. Ek glo die Bybel - ondanks al die vrae. Wellington: Lux Verbi.BM.

LOUBSER, J.A. 2004. Moving beyond colonialist discourse: understanding oral theory and cultural difference in the context of media-analysis. (In Draper, J.A., ed. Orality, literacy and colonialism in antiquity. Leiden: Brill. p. 6582.)

MALULEKE, T.S. 2000. The Bible among African Christians: a missiological perspective. (In Okure, T., ed. To cast fire upon the earth: Bible and mission collaborating in today's multicultural global context. Pietermaritzburg: Cluster. p. 87-112.)

MALULEKE, T.S. 2005. The next phase in the vernacular Bible discourse: echoes from Hammanskraal. Missionalia, 33(2):355-374.

MATHESON, P. 2006. The Reformation. (In Sawyer, J.F.A., ed. The Blackwell companion to the Bible and culture. Oxford: Blackwell. p. 69-84.)

MBITI, J 2005. Do you understand what you are reading? The Bible in African homes, schools and churches. Missionalia, 33(2):234-248.

McDONALD, L.M. \& SANDERS, J.A., eds. 2002. The canon debate. Peabody: Hendrickson.

MOLOBI, V. \& SAAYMAN, W.A. 2006. A time for complementarity: African theology, black theology and the AIC's. Missionalia, 34(2 \& 3):324-337.

MOSALA, I.J. 1989. Biblical hermeneutics and black theology in South Africa. Grand Rapids: Eerdmans. 
NDUNG'U, N.W. 2000. The role of the Bible in the rise of African instituted churches: the case of the Akurinu churches in Kenya. (In Dube, M.W. \& West, G.O., eds. The Bible in Africa: transactions, trajectories and trends. Leiden: Brill. p. 236-247.)

NIDITCH, S. 1996. Oral world and written word: ancient Israelite literature. Louisville: Westminster John Knox.

ODUYOYE, M.A. 1998. African women's hermeneutics. (In Maimela, S. \& König, A., eds. Initiation into theology: the rich variety of theology and hermeneutics. Pretoria: Van Schaik. p. 359-372.)

ONG, W.J. 1982. Orality and literacy: the technologizing of the Word. London: Methuen.

PEELS, H.G.L. 2009. "Hoe leest gij?" Een lectio Christiana van het Oude Testament. Theologia reformata, 52(3):236-259.

PETERSON, E.H. 2005. Christ plays in ten thousand places: a conversation in spiritual theology. London: Hodder \& Stoughton.

SAAYMAN, W.A. \& KRITZINGER, J.N.J., eds. 1996. Mission in bold humility: David Bosch's work considered. Maryknoll: Orbis Books.

SANNEH, L. 1989. Translating the message: the missionary impact on culture. Maryknoll: Orbis Books.

SAWYER, D.F. 2006. Gender. (In Sawyer, J.F.A., ed. The Blackwell companion to the Bible and culture. Oxford: Blackwell. p. 464-479.)

SCHNIEDEWIND, W.M. 2004. How the Bible became a book: the textualisation of ancient Israel. Cambridge: Cambridge University Press.

SMIT, D.J. 1998. Biblical hermeneutics: the 20th century. (In Maimela, S. \& König, A., eds. Initiation into theology: the rich variety of theology and hermeneutics. Cape Town: Van Schaik. p. 297-318.)

SMIT, D.J. 2006. Neem, lees! Hoe ons die Bybel hoor en verstaan. Wellington: Lux Verbi.BM.

SMOUTHER, W. 2006. Herstelwerk: de Geest werkt van schepping tot voleinding. Zoetermeer: Boekencentrum.

SOMMER, B.D. 2004. Unity and plurality in Jewish canons: the case of the written and oral torahs. (In Helmer, C. \& Landmesser, C., eds. One Scripture or many? Canon from biblical, theological and philosophical perspectives. Oxford: Oxford University Press. p. 108-150.)

TATE, A. 2006. Postmodernism. (In Sawyer, J.F.A., ed. The Blackwell companion to the Bible and culture. Oxford: Blackwell. p. 515-533.)

TRIMP, C. 1985. Woord, water en wijn: gedachten over prediking, doop en avondmaal. Kampen: Kok. (Bij-tijds geloven.)

VAN DE BEEK, A. 2001. Ontmaskering: christelijk geloof en cultuur. Zoetermeer: Meinema.

VAN DE BEEK, A. 2006. Van Kant tot Kuitert: de belangrijkste theologen uit de 19 e en 20e eeuw. Kampen: Kok.

VAN DEN BELT, H. 2007. “... Die gesproken heeft door de profeten”: de Schrift in de context van de pneumatologie. Theologia reformata, 50(4):346-360.

VAN DEN BRINK, G. 2004. Een publieke zaak: theologie tussen geloof en wetenschap. Zoetermeer: Boekencentrum.

VAN DER DUSSEN, A. 2007. Kruisbestuiving tussen exegese en dogmatiek: de gereformeerde traditie en de kloof tussen Bijbelwetenschap en dogmatiek. (In Den Hertog, G.C. \& Van der Kooi, C., reds. Tussen leer en lezen: de spanning tussen Bijbelwetenschap en Geloofsleer. Kampen: Kok. p. 21-32.) 
VAN DER KOOI, C. 2002. Als in een spiegel: God kennen volgens Calvijn en Barth: een tweeluik. 2e dr. Kampen: Kok.

VAN DER TOORN, K. 2007. Scribal culture and the making of the Hebrew Bible. Cambridge: Harvard University Press.

VAN DER WALT, B.J. 2008. Probleme rondom die Bybel in die gereformeerde teologie: besinning vanuit 'n Christelike filosofie. In die Skriflig, 42(4):635664.

VAN DER WALT, T. 2008. Hoe moet 'n Gereformeerde teoloog met die Bybel omgaan? In die Skriflig, 42(4):755-772.

VAN KEULEN, D. 2003. Bijbel en dogmatiek: Schriftbeschouwing en Schriftgebruik in het dogmatisch werk van A. Kuyper, H. Bavinck en G.C. Berkouwer. Kampen: Kok. (D.Th. dissertation, VU.)

VAN RENSBURG, F.J. \& KRUGER, F. 2008. Leer die Bybel self verklaar: 'n omvattende gids om die krag van die Bybel as Woord van God te ontsluit. Vereeniging: Christelike Uitgewersmaatskappy.

VAN WYK, J.H. 1993. Homo dei: 'n prinsipiële besinning oor enkele mensbeskouings, waaronder dié van Calvyn. In die Skriflig, 27 (Supplementum 1).

VAN WYK, J.H. 2008. Oor die Bybel, Bybellees en etiek: in gesprek met Gerrie Snyman. In die Skriflig, 42(4):685-707.

VEENHOF, J. 2008. Cornelis Veenhof als theoloog. (In Harinck, G., red. "Niets is overbodig, niets is toevallig": leven en werk van Cornelis Veenhof. Barneveld: De Vuurbaak. p. 242-269.) (Ad Charta-reeks 13.)

VERKERK, M.J. 1997. Sekse als antwoord. Amsterdam: Buijten \& Schipperheijn. (Verantwoording, 12.)

VERKERK, M.J. \& VERKERK-VEGTER, N. 2005. Homo sexualis: waarom wij met twee zijn! (In Buijs, G., Blokhuis, P., Griffioen, S. \& Kuiper, R., reds. Homo respondens: verkenningen rond het mens-zijn. Amsterdam: Buijten \& Schipperheijn. p. 157-168.) (Verantwoording, 22.)

WATTS, J.W., ed. 2001. Persia and Torah: the theory of imperial authorization of the Pentateuch. Vol 17. Atlanta: Society of Biblical Literature.

WEST, G.O. 1991. Biblical hermeneutics of liberation: modes of reading the Bible in the South African context. Pietermaritzburg: Cluster.

WEST, G.O. 2000. Being partially constituted by work with others: biblical scholars being missionized by ordinary readers of the Bible. (In Okure, T., ed. To cast fire upon the earth: Bible and mission collaborating in today's multicultural global context. Pietermaritzburg: Cluster. p. 162-177.)

WEST, G.O. 2006. Contextuality. (In Sawyer, J.F.A., ed. The Blackwell companion to the Bible and culture. Oxford: Blackwell. p. 399-413.)

WEST, G.O. 2008. Interrogating the comparative paradigm in African biblical scholarship. (In De Wit, J.H. \& West, G.O., eds. African and European readers of the Bible: a quest of a shared meaning. Leiden: Brill. p. 37-64.)

WIELENGA, B. 1992. The Bible in a changing South Africa: the quest for a responsible biblical hermeneutic in mission. Missionalia, 20(1):28-37.

WIELENGA, B. 1994. Zendingshermeneutiek: een inleiding. (In Bouma, J., Dekker, J., Van Leeuwen, A.M. \& Muller, K., reds. Begeleidend schrijven: 25 jaar theologische studie begeleiding. Amsterdam: Buijten \& Schipperheijn. p. 224-235.)

WIELENGA, B. 1998. Verbond en zending: een verbondsmatige benadering van zending. Kampen: Mondiss. (D.Th. dissertation, Unisa.) 
WIELENGA, B. 2009. Niet iedereen een leraar: Henk de Jong in Afrika. (In Bouma, J., Gerkema, F. \& Mudde, J.M., reds. Verrassend vertrouwd: een halve eeuw verkondiging en theologie van Henk de Jong. Franeker: Van Wijnen. p. 77-92.)

WOLTERSTORFF, N. 2004. The unity behind the canon. (In Helmer, C. \& Landmesser, C., eds. One Scripture or many? Canon from biblical, theological and philosophical perspectives. Oxford: Oxford University Press. p. 217-232.)

WRIGHT, C.J.H. 2006. The mission of God: unlocking the Bible's grand narrative. Downers Grove: IVP-Academic.

\section{Key concepts:}

Bible readers, ordinary

Bible readers, professional

Bible reading together, ecclesiology

Bible reading together, gender sensitive

Bible reading together, pneumatology

Bible reading together, spirituality

\section{Kernbegrippe:}

Bybellesers, gewone

Bybellesers, vakmatige

gesamentlike Bybellees, ekklesiologie

gesamentlike Bybellees, geslagsvriendelike

gesamentlike Bybellees, pneumatologie

gesamentlike Bybellees, spiritualiteit 
